\title{
Synthesis and Characterization of Mercury(II) Complexes Containing 2,9-Dimethyl-1,10-phenanthroline by Sonochemical Method
}

\author{
M. Ranjbar, ${ }^{1}$ E. Malakooti, ${ }^{2}$ and S. Sheshmani ${ }^{2}$ \\ ${ }^{1}$ Department of Chemical Technologies, Iranian Research Organization for Science and Technology, \\ P.O. Box 33535-111, Tehran 3353136846, Iran \\ ${ }^{2}$ Department of Chemistry, Shahr-e Ray Branch, Islamic Azad University, Tehran, Iran
}

Correspondence should be addressed to M. Ranjbar; ma_randjbar@yahoo.com

Received 29 June 2012; Revised 9 September 2012; Accepted 1 October 2012

Academic Editor: José M. G. Martinho

Copyright @ 2013 M. Ranjbar et al. This is an open access article distributed under the Creative Commons Attribution License, which permits unrestricted use, distribution, and reproduction in any medium, provided the original work is properly cited.

Synthesis and characterization of microstructured crystalline complexes of $\left[\mathrm{HgI}_{2}\left(\mathrm{C}_{14} \mathrm{H}_{12} \mathrm{~N}_{2}\right)\right]$ and $\left[\operatorname{HgBr}_{2}\left(\mathrm{C}_{14} \mathrm{H}_{12} \mathrm{~N}_{2}\right)\right]$ were carried out from the reaction between 2,9-dimethyl-1,10-phenanthroline, mercury acetate, $\mathrm{KI}$, and $\mathrm{KBr}$, respectively, in methanol by sonochemical method. The reaction conditions were optimized under ultrasonic irradiations and without it. Characterization of the complexes was performed by elemental analysis, XRD, SEM, FTIR, and thermal analysis (TG/DTA). The results showed that sonochemical method caused significant reduction of the reaction time. Then the products were put under supercritical condition in a Teflon-lined, stainless-steel Parr bomb container and heated at $150^{\circ} \mathrm{C}$ for $48 \mathrm{~h}$. The results showed that the chemical formulas of the complexes were not changed; however, the particle sizes were reduced and porosity increased.

\section{Introduction}

In recent years, the preparation of transition metal structures, as important semiconductors material, has attracted wide attention. Their excellent physical and chemical properties in various fields, such as catalysis, sensors, solar cells, photo detector, light emitting diodes, and laser communication, have made them very attractive [1-4] and promising material. They have found established uses [5-8] such as for catalysts, infrared detectors as well as many effective methods such as nonaqueous system microware radiation, gamma radiation, pyrolysis, precursors, and hydrothermal synthesis for the preparation of nanostructures. The sonochemical method has been proved to be a useful method to obtain novel materials. The chemical effects of ultrasonic irradiation arise from the application of powerful ultrasound radiation $(20 \mathrm{KHz}-10 \mathrm{MHz})$ [9-11]. This is due to acoustic-cavitations growth and implosive collapse of bubbles in a liquid medium, which result in high temperatures and pressures.

1,10 -Phenanthroline is the basic chemical moiety that leads to an important class of chelating agent [12]. The choice of phenanthroline is mainly due to two factors. This hermetic moiety can provide a further binding site for metal ions. Therefore, polyamine macrocyclics containing this moiety are expected to form more stable complexes than saturated polyamine ligands containing the same number of nitrogen donors. The insertion of phenanthroline in a macrocyclic framework may allow the resulting metal complexes to be solubilized in a polar solvent due to the hydrophobic characteristics displayed by this aromatic unit. It has therefore been increasingly used in both analytical and preparative coordination chemistry [13]. Metal complexes containing ligands such as 1,10-phenathroline and bipyridine have gained importance because of their versatile roles as building blocks for the synthesis of metallodendrimers for supramolecular assemblies in analytical chemistry, catalysis, electrochemistry, ring-opening metathesis polymerization, and biochemistry [14]. Alizadeh et al. have prepared $\left[\mathrm{HgBr}_{2}\left(\mathrm{C}_{14} \mathrm{H}_{12} \mathrm{~N}_{2}\right)\right]$ by ordinary thermal gradient method from 2,9-dimethyl-1,10-phenanthroline and $\mathrm{HgBr}_{2}$, wherein the single crystals were obtained after one week (yield; $0.51 \mathrm{~g}$, $74.7 \%$ ), from diffusion of methanol to a colorless solution of 

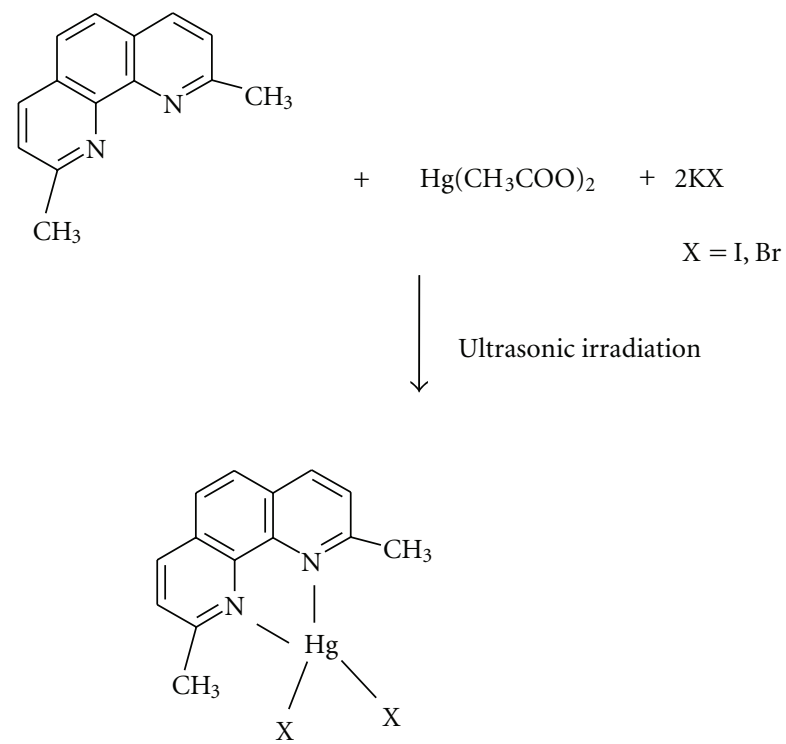

Scheme 1: The synthetic method for the preparation of the complexes.

DMSO [15]. In the present paper we describe sonochemical preparation of the micron-sized, block-shaped complexes of mercury, $\left[\mathrm{HgI}_{2}\left(\mathrm{C}_{14} \mathrm{H}_{12} \mathrm{~N}_{2}\right)\right]$ and $\left[\mathrm{HgBr}_{2}\left(\mathrm{C}_{14} \mathrm{H}_{12} \mathrm{~N}_{2}\right)\right]$ in 30 minutes only. The thermal behavior of the complexes is also discussed.

\section{Experimental}

2.1. Reagents. All reagents and solvents for the preparation and analysis were commercially available and were used as received.

2.2. Apparatus. Infrared spectra were measured with an IR spectra $\left(4000-400 \mathrm{~cm}^{-1}\right)$ on a Bruker tensor 27 spectrometer in a $\mathrm{KBr}$ matrix. X-ray diffraction powder patterns are obtained using a Philips diffractometer of x' pert company. Thermogravimetric diffraction thermal analysis (TG-DTG) was carried out using a thermal gravimetric analysis instrument (pyres) diamond. Thermo gravimetric and compounds were heated in a nitrogen atmosphere from $10-600^{\circ} \mathrm{C}$ samples a heating rate of $10^{\circ} \mathrm{C} / \mathrm{min}$. Elemental analysis was performed with a Perkin-Elmer 240 apparatus. The samples were characterized with a scanning electron microscope (SEM) and energy dispersive X-ray (EDX) techniques (Philips XL30) with gold coating. A multiwave ultrasonic generator operating at $20 \mathrm{KHZ}$ with a maximum power output of $400 \mathrm{~W}$, equipped with a convertor/transducer and titanium oscillator (horn), $12.5 \mathrm{~mm}$ in diameter, was used for the ultrasonic irradiation.

\subsection{Sonochemical Preparation of Microstructures Crystalline} Complexes of $\left[\mathrm{HgI}_{2}\left(\mathrm{C}_{14} \mathrm{H}_{12} \mathrm{~N}_{2}\right)\right]$ and $\left[\left(\mathrm{HgBr}_{2}\left(\mathrm{C}_{14} \mathrm{H}_{12} \mathrm{~N}_{2}\right)\right]\right.$. For sonochemical preparation of the designated microstructures, a solution of $\mathrm{Hg}\left(\mathrm{CH}_{3} \mathrm{COO}\right)_{2}(0.477 \mathrm{~g}, 0.5 \mathrm{mmol})$ and
$\mathrm{KX}(1 \mathrm{mmol}, \mathrm{X}=\mathrm{I}, \mathrm{Br})$ in methanol $(20 \mathrm{~mL})$ as solvent was placed in a vessel of high-density ultrasonic probe, operating at $20 \mathrm{KHz}$ with maximum power output of $400 \mathrm{~W}$. Then, 2,9-dimethyl-1,10-phenanthroline ligand $(10 \mathrm{~mL})$ in methanol was added dropwise in $30 \mathrm{~min}$. White microcrystalline products were separated by centrifuging at $4000 \mathrm{rpm}$ in $20 \mathrm{~min}$, washed with acetone, and methanol and dried under nitrogen. The pure crystalline $\mathrm{Hg}(\mathrm{II})$ complexes were obtained in $72 \%$ and $68 \%$ yield, respectively, decomd. $>300^{\circ} \mathrm{C}$. Anal. calcd. for $\mathrm{C}_{14} \mathrm{H}_{12} \mathrm{HgN}_{2} \mathrm{I}_{2}$ (\%): C 25.30, $\mathrm{H} \mathrm{1.81}$, $\mathrm{N}$ 4.22; found: $\mathrm{C} 25.27, \mathrm{H} 1.83, \mathrm{~N} 4.15$ and Anal. calcd. for $\mathrm{C}_{14} \mathrm{H}_{12} \mathrm{HgN}_{2} \mathrm{Br}_{2}$ (\%): C 29.56, $\mathrm{H}$ 2.11, N 4.92; found: C 29.47, H 2.00, N 4.89. FT-IR ( $\mathrm{KBr}$ pellet, $\mathrm{cm}^{-1}$ ) selected bands for $\left[\mathrm{HgI}_{2}\left(\mathrm{C}_{14} \mathrm{H}_{12} \mathrm{~N}_{2}\right)\right]$ : $v=3390(\mathrm{~b}), 1615(\mathrm{~s}), 1590(\mathrm{w})$, $1550(\mathrm{~s}), \quad 1500(\mathrm{w}), 1433(\mathrm{w}), 1366(\mathrm{~s}), 1247(\mathrm{w}), 1222(\mathrm{w})$, 1149(w), 1085(w), 1028(w), 934(w), 863(s), 804(w), 769(w), 728(w), 679(w) 651(w), 547(w), 435(w). [ $\left.\mathrm{HgBr}_{2}\left(\mathrm{C}_{14} \mathrm{H}_{12} \mathrm{~N}_{2}\right)\right]$ : $v=3413(\mathrm{~b}), 3049(\mathrm{w}), 1590(\mathrm{w}), 1502(\mathrm{~s}), 1374(\mathrm{w}), 1106(\mathrm{w})$, 867(s), 773(w), 728(w), 550(w), 436(w).

Then the complexes $(0.2 \mathrm{~g})$ and water $(10 \mathrm{~mL})$ were placed in a $50 \mathrm{~mL}$ Teflon-lined, stainless-steel Parr bomb container and heated at $150^{\circ} \mathrm{C}$ for $48 \mathrm{~h}$. After cooling slowly to room temperature, red block-shaped crystals of 1 were collected by centrifugation at $4000 \mathrm{rpm}$ for $20 \mathrm{~min}$ and washed by methanol and acetone. The white precipitate was dried under nitrogen. Anal. calcd. for $\mathrm{C}_{14} \mathrm{H}_{12} \mathrm{HgN}_{2} \mathrm{I}_{2}$ (\%): C 25.30, $\mathrm{H} \mathrm{1.81}$, $\mathrm{N}$ 4.22; found: C 25.29, $\mathrm{H} 1.86, \mathrm{~N} 4.19$ and Anal. calcd. for $\mathrm{C}_{14} \mathrm{H}_{12} \mathrm{HgN}_{2} \mathrm{Br}_{2}$ (\%): C 29.56, H 2.11, N 4.92; found: C 29.48, $\mathrm{H} 2.00, \mathrm{~N}$ 4.90. FT-IR ( $\mathrm{KBr}$ pellet, $\mathrm{cm}^{-1}$ ) selected bands for $\left[\mathrm{HgI}_{2}\left(\mathrm{C}_{14} \mathrm{H}_{12} \mathrm{~N}_{2}\right)\right]: v=3445(\mathrm{~b}), 2919(\mathrm{w}), 1590(\mathrm{w}), 1554(\mathrm{w})$, 1500(s), 1435(w), 1366(s), 1148(w), 1023(w), 862(s), 804(w), 769(w), 727(w), 650(w), 547(w), 436(w).

The molar ratio of initial materials, the time of sonicating, and the power of the ultrasound were optimized. Table 1 shows the conditions of reactions and the results of elemental analysis for each reaction. The ultrasonic generator automatically adjusted the power level. The wave amplitude in each experiment was adjusted as needed.

\section{Result and Discussion}

3.1. Synthesis and Characterization of $H g(I I)$ Complexes of Neocuprine and Halide Ion. Reaction between 2,9-dimethyl1,10-phenanthroline as ligand with a mixture of mercury(II) acetate and potassium iodide and potassium bromide in methanol under ultrasonic irradiations leads to a formation of colorless block-shaped crystals (Scheme 1). These complexes displayed distinct elemental analysis consistent with the formula $\left[\mathrm{HgI}_{2}\left(\mathrm{C}_{14} \mathrm{H}_{12} \mathrm{~N}_{2}\right)\right]$ and $\left[\mathrm{HgBr}_{2}\left(\mathrm{C}_{14} \mathrm{H}_{12} \mathrm{~N}_{2}\right)\right]$, respectively.

To investigate the role of ultrasound irradiation on the composition, size and purity of the reactions of $\mathrm{Hg}\left(\mathrm{CH}_{3} \mathrm{COO}\right)_{2}$ with $\mathrm{KX}, \mathrm{X}=\mathrm{I}$ and $\mathrm{Br}$, and 2,9-dimethyl1,10-phenanthroline with the same conditions as the reaction no. 6 without any ultrasound irradiation and by mechanical stirring were performed (Table 1, reaction no. 6). The elemental analysis of the product after 30 minutes of the reaction showed that appropriate reaction time is indeed 30 minutes under ultrasonic irradiation. The XRD patterns show that the 


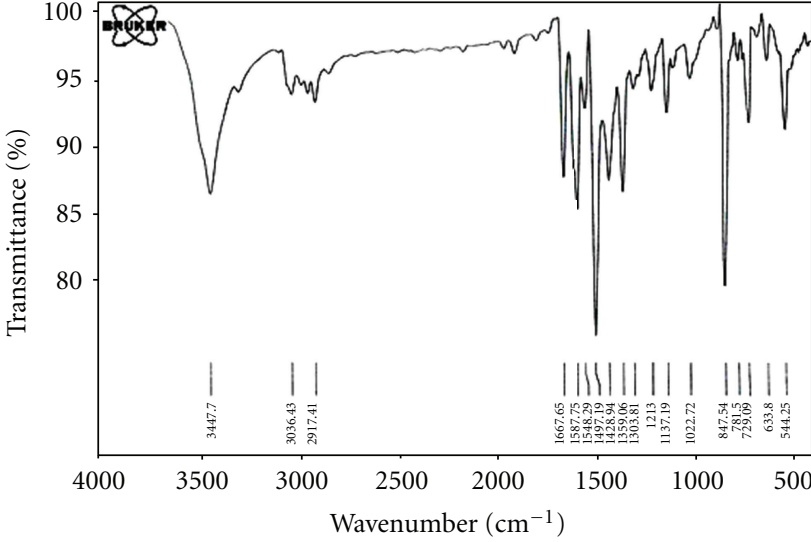

(a)

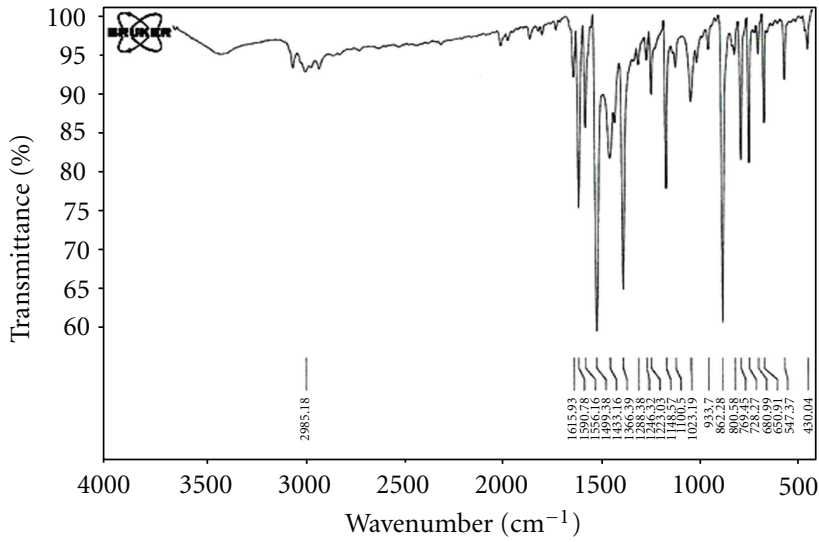

(b)

FIGURE 1: IR spectrum of (a) 2,9-dimethyl-1,10-phenanthroline and (b) $\left[\mathrm{HgI}_{2}\left(\mathrm{C}_{14} \mathrm{H}_{12} \mathrm{~N}_{2}\right)\right]$.

TABLE 1: Experimental conditions for the preparation of the microcrystalline $\mathrm{Hg}(\mathrm{II})$ complexes.

\begin{tabular}{|c|c|c|c|c|c|c|}
\hline Sample & $\mathrm{Hg}\left(\mathrm{CH}_{3} \mathrm{COO}\right)_{2}$ & $\mathrm{KX}, \mathrm{X}=\mathrm{I}, \mathrm{Br}$ & Neocuprine & Sonicating time & Ultrasound power & $\begin{array}{l}\text { Elemental analysis data found for } \\
\qquad \mathrm{C}_{14} \mathrm{H}_{12} \mathrm{HgN}_{2} \mathrm{I}_{2}\end{array}$ \\
\hline 1 & $40 \mathrm{~mL}(0.5 \mathrm{mM})$ & $10 \mathrm{~mL}(1 \mathrm{~mm}) \mathrm{KI}$ & $10 \mathrm{~mL}(0.5 \mathrm{mM})$ & $1 \mathrm{~h}$ & $400 \mathrm{~W}$ & C 25.29, H 1.86, N 4.19 \\
\hline 2 & $20 \mathrm{~mL}(0.1 \mathrm{M})$ & $10 \mathrm{~mL}(1 \mathrm{~mm}) \mathrm{KI}$ & $10 \mathrm{~mL}(0.5 \mathrm{mM})$ & $40 \mathrm{~min}$ & $400 \mathrm{~W}$ & C 25.31, H 1.82, N 4.21 \\
\hline 3 & $20 \mathrm{~mL}(0.1 \mathrm{M})$ & $10 \mathrm{~mL}(1 \mathrm{~mm}) \mathrm{KI}$ & $10 \mathrm{~mL}(0.5 \mathrm{mM})$ & $30 \mathrm{~min}$ & $400 \mathrm{~W}$ & C 25.30, H 1.84, N 4.23 \\
\hline 4 & $20 \mathrm{~mL}(0.1 \mathrm{M})$ & $10 \mathrm{~mL}(1 \mathrm{~mm}) \mathrm{KI}$ & $10 \mathrm{~mL}(0.5 \mathrm{mM})$ & $20 \mathrm{~min}$ & $400 \mathrm{~W}$ & C 30.21, H 2.82, N 3.24 \\
\hline 5 & $20 \mathrm{~mL}(0.1 \mathrm{M})$ & $10 \mathrm{~mL}(1 \mathrm{~mm}) \mathrm{KI}$ & $10 \mathrm{~mL}(0.5 \mathrm{mM})$ & $10 \mathrm{~min}$ & $400 \mathrm{~W}$ & C 31.01, H 2.91, N 5.2 \\
\hline 6 & $20 \mathrm{~mL}(0.1 \mathrm{M})$ & $10 \mathrm{~mL}(1 \mathrm{~mm}) \mathrm{KI}$ & $10 \mathrm{~mL}(0.5 \mathrm{mM})$ & $30 \mathrm{~min}$ & $\begin{array}{l}\text { Without } \\
\text { ultrasound }\end{array}$ & C $25.30, \mathrm{H} 1.84, \mathrm{~N} 4.23$ \\
\hline
\end{tabular}

obtained product is $\left[\mathrm{HgI}_{2}\left(\mathrm{C}_{14} \mathrm{H}_{12} \mathrm{~N}_{2}\right)\right]$ with high crystallinity for the products obtained by sonicating. The results of elemental analysis showed that the products obtained without ultrasound under the conditions defined were not pure since the percentages of $\mathrm{C}, \mathrm{N}, \mathrm{H}$, and $\mathrm{Hg}$ were not compatible with the chemical formulas $\left[\mathrm{HgX}_{2}\left(\mathrm{C}_{14} \mathrm{H}_{12} \mathrm{~N}_{2}\right)\right], \mathrm{X}=\mathrm{I}, \mathrm{Br}$. Hence, we can conclude that ultrasonic irradiation has significant role in decreasing the reaction time drastically.

The FTIR spectra of $\mathrm{Hg}$ (II) complexes (see Figures 1(a) and $1(\mathrm{~b})$ ) exhibit the characteristic aromatic rings vibrations at 1400 and $1600 \mathrm{~cm}^{-1}$ region. The aromatic ring band for free neocuprine in IR spectrum at 1667 to $1428 \mathrm{~cm}^{-1}$ is shifted to lower frequencies upon complexation. The band at $1587 \mathrm{~cm}^{-1}$ that is related to the $\mathrm{NH}$ bonding vibration of free ligand has also shifted to lower frequency (i.e., $1556 \mathrm{~cm}^{-1}$ ) due to complexation. The broadbands occurring at 3036 to $2850 \mathrm{~cm}^{-1}$ can be assigned to the $\mathrm{C}-\mathrm{H}\left(\mathrm{CH}_{3}\right)$ groups of ligand. The $\mathrm{Hg}-\mathrm{N}, \mathrm{Hg}-\mathrm{Br}$, and $\mathrm{Hg}-\mathrm{I}$ bonds are reflected by their new bands at 547 and $435 \mathrm{~cm}^{-1}$ [16]. IR spectra of the ligand and complexes are shown in Figure 1.

The energy dispersive X-ray analysis (EDX) also confirmed the presence of $\mathrm{Hg}$ and halide atoms (Figure 2). XRD pattern of the complex, $\left[\mathrm{HgI}_{2}\left(\mathrm{C}_{14} \mathrm{H}_{12} \mathrm{~N}_{2}\right)\right]$, at room temperature is shown in Figure 3 . XRD pattern is not consistent with the spectrum of other 2,9-dimethyl-1,10phenanthroline complexes. The peaks are sharp due to the microcrystalin nature of the complex $\left[\operatorname{HgI}_{2}\left(\mathrm{C}_{14} \mathrm{H}_{12} \mathrm{~N}_{2}\right)\right]$. It shows that XRD pattern of the complex is different from previous reported complexes [15].

The morphology of the products that is examined by optical microscopy is shown in Figure 4. The SEM images of the products obtained without and with using ultrasounds are shown in Figures 5 and 6, respectively. From the micrographs, it was observed that the particle sizes of the complexes that have been prepared without ultrasonic irradiations are about more than 10 microns, while the particle sizes of the complexes which have been prepared under ultrasonic irradiations are significantly decreased. Typical SEM images of obtained microcrystals of complexes, $\left[\mathrm{HgI}_{2}\left(\mathrm{C}_{14} \mathrm{H}_{12} \mathrm{~N}_{2}\right)\right]$ and $\left[\mathrm{HgBr}_{2}\left(\mathrm{C}_{14} \mathrm{H}_{12} \mathrm{~N}_{2}\right)\right]$, are shown in Figure 5. It is established that the microcrystals sizes range from 1 to 3 microns.

Attempts were made to convert the microsized crystals obtained by sonication to nanosized ones. In our earlier work we could obtain nanostructures of $\mathrm{PbOHBr}$ by thermal treatment method [6]. The crystalline complexes of $\left[\mathrm{HgI}_{2}\left(\mathrm{C}_{14} \mathrm{H}_{12} \mathrm{~N}_{2}\right)\right.$ and $\left[\mathrm{HgBr}_{2}\left(\mathrm{C}_{14} \mathrm{H}_{12} \mathrm{~N}_{2}\right)\right]$ were thus put in an autoclave for thermal decomposition of the complexes for preparation of nanostructures of $\mathrm{HgI}_{2}$ and $\mathrm{HgBr}_{2}$. After $48 \mathrm{~h}$ at $150^{\circ} \mathrm{C}$ in an autoclave, the complexes were not decomposed, just the particle sizes decreased. The SEM micrograph of the products is shown in Figure 7. From the micrograph, it was observed that the particle sizes were decreased and porosity was increased after hydrothermal treatments. 


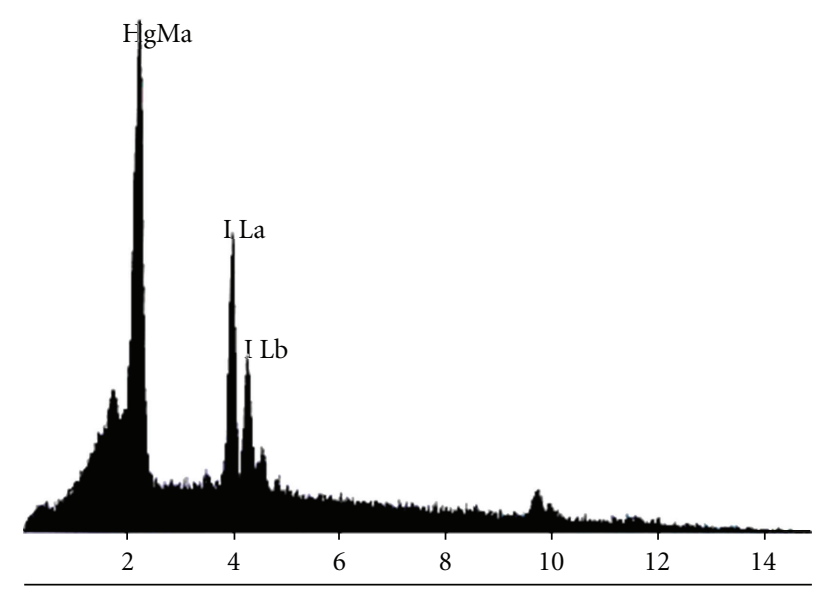

EDAX ZAF quantification (standardless)

Element normalized

\begin{tabular}{lll} 
Element & $\mathrm{Wt} \%$ & At\% \\
\hline HgM & 51.88 & 40.55 \\
I L & 48.12 & 59.45 \\
Total & 100 & 100
\end{tabular}

Figure 2: EDX spectrum of $\left[\mathrm{HgI}_{2}\left(\mathrm{C}_{14} \mathrm{H}_{12} \mathrm{~N}_{2}\right)\right]$.

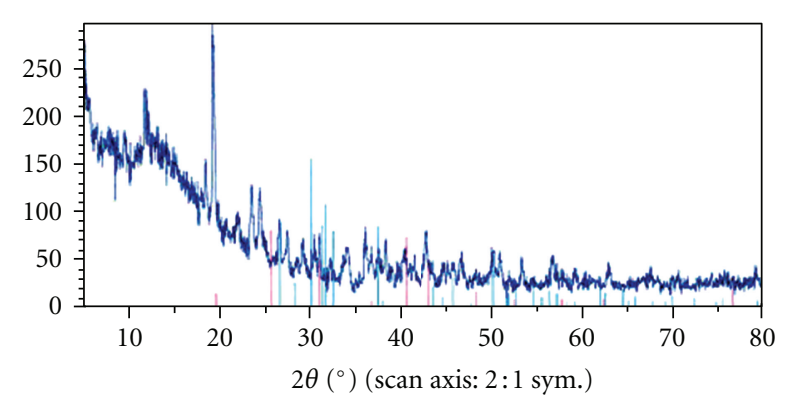

FIGURE 3: XRD pattern of $\left[\mathrm{HgI}_{2}\left(\mathrm{C}_{14} \mathrm{H}_{12} \mathrm{~N}_{2}\right)\right]$.

To examine the thermal stability of the $\mathrm{Hg}$ (II) complexes, $\left[\mathrm{HgI}_{2}\left(\mathrm{C}_{14} \mathrm{H}_{12} \mathrm{~N}_{2}\right)\right]$ and $\left[\mathrm{HgBr}_{2}\left(\mathrm{C}_{14} \mathrm{H}_{12} \mathrm{~N}_{2}\right)\right]$, thermo gravimetric analyses (TGA) were carried out from room temperature to $600^{\circ} \mathrm{C}$ under air flow (Figure 8). In the case of $\left[\mathrm{HgBr}_{2}\left(\mathrm{C}_{14} \mathrm{H}_{12} \mathrm{~N}_{2}\right)\right]$, TGA shows that the complex is stable up to $314^{\circ} \mathrm{C}$. Decomposition of the complex occurs between 314 and $400^{\circ} \mathrm{C}$ with a mass loss of $63.2 \%$. The weight loss between 314 to $344^{\circ} \mathrm{C}$ may be ascribed to the removal of 2,9-dimethyl1,10-phenanthroline, and the mass loss between 344 to $400^{\circ} \mathrm{C}$ in a static atmosphere of oxygen is ascribed to removal of bromide atoms. The final decomposition of the complex, $\left[\mathrm{HgBr}_{2}\left(\mathrm{C}_{14} \mathrm{H}_{12} \mathrm{~N}_{2}\right)\right]$, appears to be $\mathrm{HgO}$ as decompositions occurs under oxygen atmosphere.

\section{Conclusion}

We have demonstrated that the complexation reactions between 2,9-dimethyl-1,10-phenanthroline and $\mathrm{Hg}\left(\mathrm{CH}_{3} \mathrm{COO}\right)_{2}$ in presence of halide ions $(\mathrm{KX}, \mathrm{X}=\mathrm{I}$, $\mathrm{Br}$ ) under ultrasonic irradiations lead to the formation of thermally stable complexes, $\left[\mathrm{HgI}_{2}\left(\mathrm{C}_{14} \mathrm{H}_{12} \mathrm{~N}_{2}\right)\right.$ and $\left[\mathrm{HgBr}_{2}\left(\mathrm{C}_{14} \mathrm{H}_{12} \mathrm{~N}_{2}\right)\right]$, respectively. Halide ions serve as

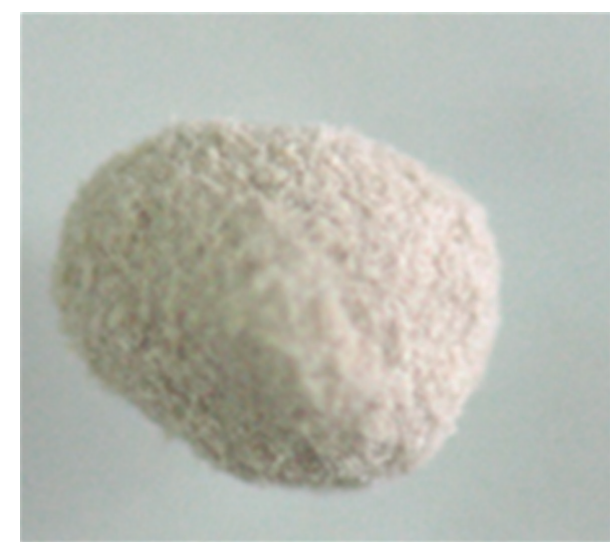

FIGURE 4: Optical microscopy picture of microcrystals of $\left[\mathrm{HgI}_{2}\left(\mathrm{C}_{14} \mathrm{H}_{12} \mathrm{~N}_{2}\right)\right]$.

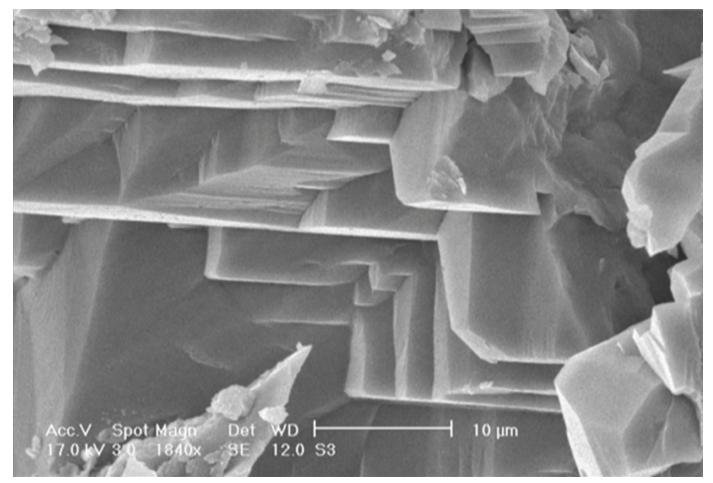

FIgURE 5: SEM micrograph of $\left[\mathrm{HgI}_{2}\left(\mathrm{C}_{14} \mathrm{H}_{12} \mathrm{~N}_{2}\right)\right]$ complex, prepared without ultrasonic irradiations.

ligands, and they neutralizethe positive charges on $\mathrm{Hg}$ (II) ions. In conclusion, the work establishes a simple, onestep, and fast sonochemical route to synthesis of different microstructured, stable, and pure complexes. To the best of our knowledge, it is probably the first time that a new micro structured complex, $\left[\mathrm{HgI}_{2}\left(\mathrm{C}_{14} \mathrm{H}_{12} \mathrm{~N}_{2}\right)\right]$, has been prepared. This fast economical and simple method offers an attractive route for industrial scale synthesis of metalorganic complexes for application in dye-sensitized solar cells. Because this method does not require special conditions of high temperatures, extended durations of reactions, or high pressures, it will contribute immensely in reducing the cost of production of solar cells leading to greater ramifications in reducing carbon footprint and more use of solar energy in near future.

\section{Acknowledgments}

The authors would like to express gratitude for support of Nanotechnology Initiative Council, Iranian Research Organization for Science and Technology, and Islamic Azad University, Shahr-e Ray branch. 


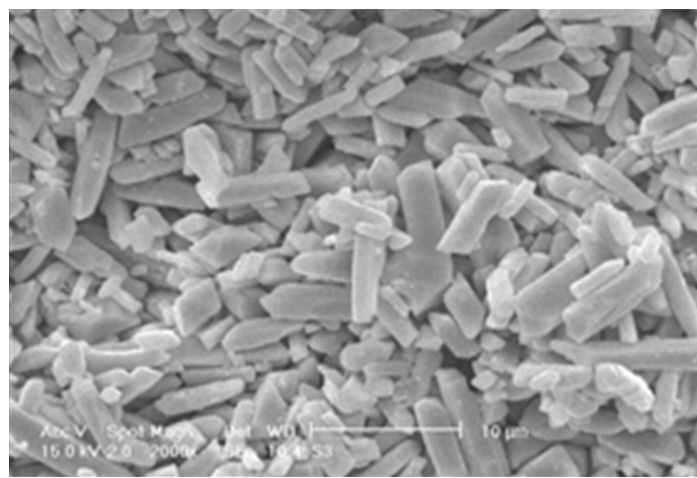

(a)

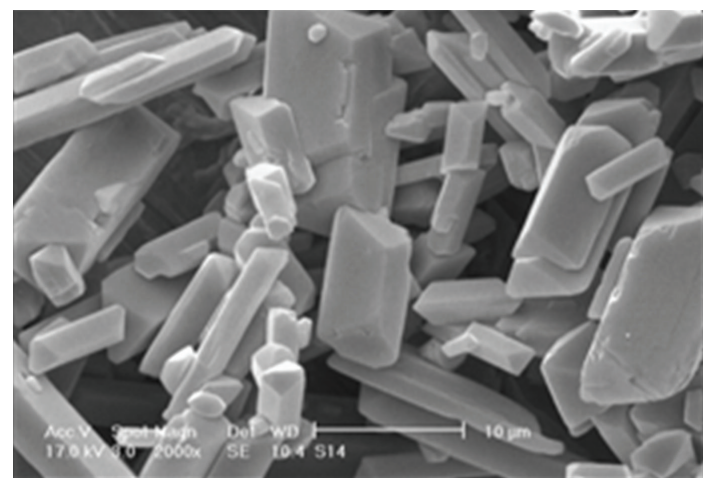

(b)

FigURE 6: SEM micrograph of (a) $\left[\mathrm{HgI}_{2}\left(\mathrm{C}_{14} \mathrm{H}_{12} \mathrm{~N}_{2}\right)\right]$ and (b) $\left[\mathrm{HgBr}_{2}\left(\mathrm{C}_{14} \mathrm{H}_{12} \mathrm{~N}_{2}\right)\right]$ prepared by sonochemical method.

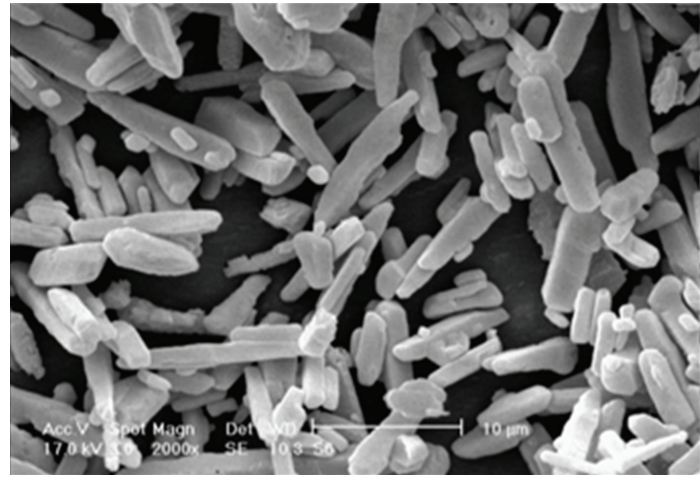

(a)

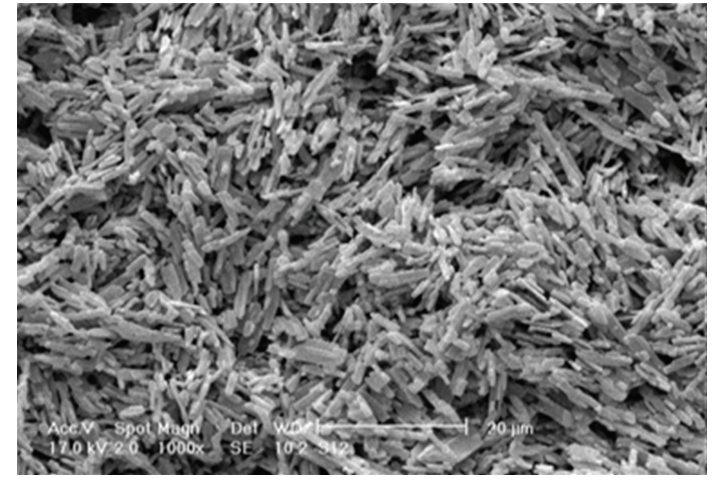

(b)

Figure 7: SEM micrograph of (a) $\left[\mathrm{HgI}_{2}\left(\mathrm{C}_{14} \mathrm{H}_{12} \mathrm{~N}_{2}\right)\right]$ and (b) $\left[\mathrm{HgBr}_{2}\left(\mathrm{C}_{14} \mathrm{H}_{12} \mathrm{~N}_{2}\right)\right]$ after hydrothermal treatment.

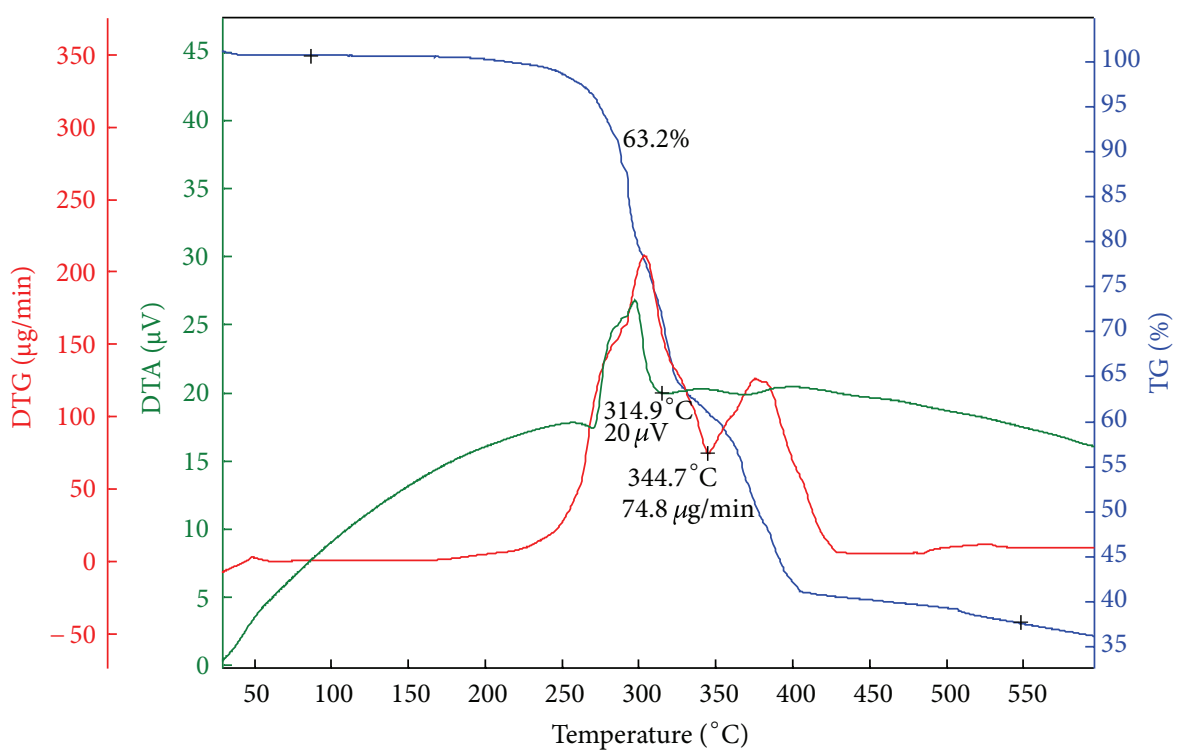

FIgURE 8: TG/DTA diagrams of $\left[\mathrm{HgBr}_{2}\left(\mathrm{C}_{14} \mathrm{H}_{12} \mathrm{~N}_{2}\right)\right]$. 


\section{References}

[1] C. Q. Xu, Z. C. Zhang, and Q. Ye, "A novel facile method to metal sulfide (metal=Cd, Ag, Hg) nano-crystallite," Materials Letters, vol. 58, no. 11, pp. 1671-1676, 2004.

[2] P. Sreekumari Nair, T. Radhakrishnan, N. Revaprasadu, G. A. Kolawole, and P. O'Brien, "The synthesis of $\mathrm{HgS}$ nanoparticles in polystyrene matrix," Journal of Materials Chemistry, vol. 14, no. 4, pp. 581-584, 2004.

[3] A. Askarinejad and A. Morsali, "Synthesis and characterization of mercury oxide unusual nanostructures by ultrasonic method," Chemical Engineering Journal, vol. 153, no. 1-3, pp. 183-186, 2009.

[4] H. H. Michael, M. Samuel, F. Hennig et al., "Room-temperature ultraviolet nanowire nanolasers," Science, vol. 292, no. 5523, pp. 1897-1899, 2001.

[5] V. N. Konev, V. N. Chebotin, and S. A. Fomenkov, "Diffusion phenomena in nonstoichiometric copper sulfide and selenide," Inorganic Materials, vol. 21, pp. 166-170, 1985.

[6] M. Ranjbar, O. Celik, S. H. Mahmoudi Najafi, S. Sheshmani, and N. Akbari Mobarakeh, "Synthesis of lead(II) minoxidil coordination polymer: a new precursor for lead(II) oxide and lead(II) hydroxyl bromide," Journal of Inorganic and Organometallic Polymers, vol. 22, no. 4, pp. 837-844, 2012.

[7] M. Ranjbar, S. H. Mahmoudi Najafi, N. Shahsavan, and M. Yousefi, "Synthesis of zinc(II)oxide wurtzite nano crystals via $\mathrm{Zn}$ (II)minoxidil nanocomposite as a new precursor," International Journal of NanoScience and Nanotechnology, vol. 7, pp. 147-152, 2011.

[8] M. L. Hu, A. Morsali, and L. Aboutorabi, "Lead(II) carboxylate supramolecular compounds: coordination modes, structures and nano-structures aspects," Coordination Chemistry Reviews, vol. 255, no. 23-24, pp. 2821-2859, 2011.

[9] R. S. Yadav, P. Mishra, and A. C. Pandey, "Growth mechanism and optical property of $\mathrm{ZnO}$ nanoparticles synthesized by sonochemical method," Ultrasonics Sonochemistry, vol. 15, no. 5, pp. 863-868, 2008.

[10] A. Askarinejad and A. Morsali, "Synthesis and characterization of mercury oxide unusual nanostructures by ultrasonic method," Chemical Engineering Journal, vol. 153, no. 1-3, pp. 183-186, 2009.

[11] A. Aslani, A. Morsali, and M. Zeller, "Nano-structures of two new lead(II) coordination polymers: new precursors for preparation of PbS nano-structures," Solid State Sciences, vol. 10, no. 11, pp. 1591-1597, 2008.

[12] P. G. Sammes and G. Yahioglu, "1,10-phenanthroline: a versatile ligand," Chemical Society Reviews, vol. 23, no. 5, pp. 327-334, 1994.

[13] H. Keypour, A. A. Dehghani-Firouzabadi, and H. R. Khavasi, "Synthesis and characterization of three novel manganese(II) octaaza macrocyclic Schiff base complexes containing a phenanthroline and two pyridyl units as pendant arms. X-ray crystal structure determination of one manganese(II) complex," Polyhedron, vol. 28, no. 8, pp. 1546-1550, 2009.

[14] V. Amani, N. Safari, H. R. Khavasi, and P. Mirzaei, "Iron(III) mixed-ligand complexes: synthesis, characterization and crystal structure determination of iron(III) hetero-ligand complexes containing 1,10-phenanthroline, 2,2' -bipyridine, chloride and dimethyl sulfoxide, [Fe(phen) $\mathrm{Cl}_{3}$ (DMSO)] and $\left[\mathrm{Fe}(\right.$ bipy $\left.) \mathrm{Cl}_{3}(\mathrm{DMSO})\right]$," Polyhedron, vol. 26, no. 17, pp. 4908-4914, 2007.
[15] R. Alizadeh, A. Heidari, R. Ahmadi, and V. Amani, "Dibromido(2,9-dimethyl-1,10-phenanthroline- $\kappa 2$

N,N')mercury(II)," Acta Crystallographica Section E, vol. 65, no. 5, pp. m483-m484, 2009.

[16] K. Nakamoto, Infrared and Raman Spectra of Inorganic and Coordination Compounds, Part B, New York, NY, USA, 5th edition, 1997. 

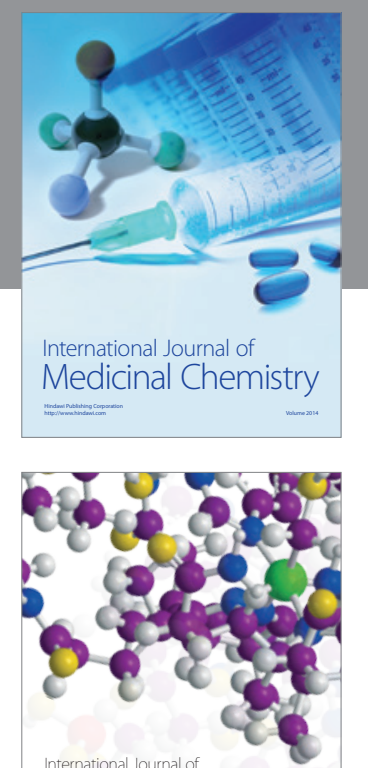

\section{Carbohydrate} Chemistry

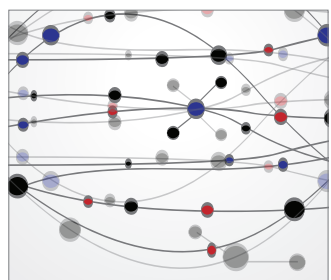

The Scientific World Journal
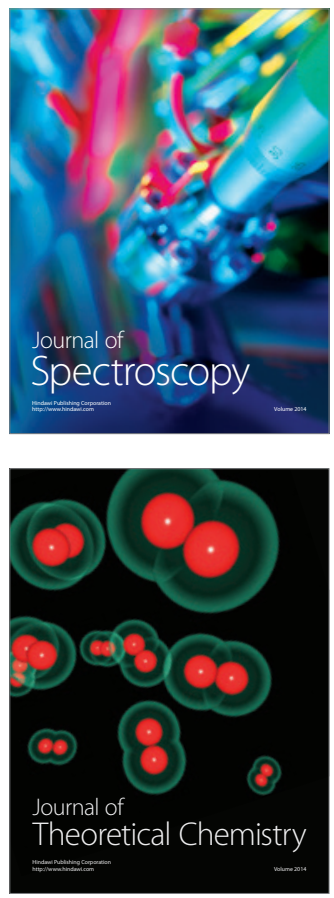
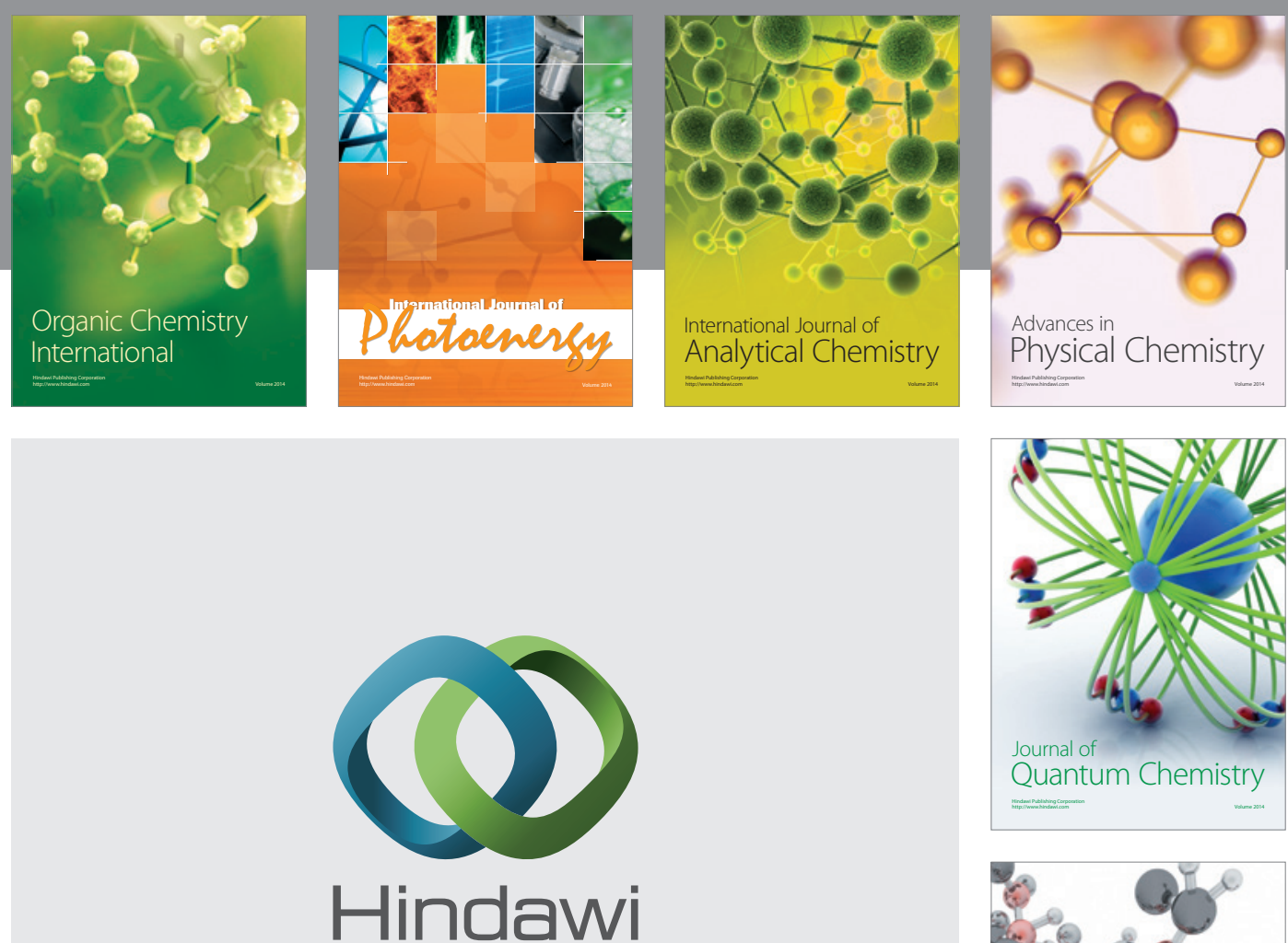

Submit your manuscripts at

http://www.hindawi.com

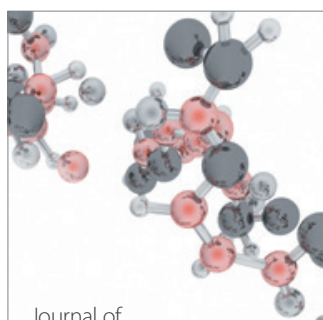

Analytical Methods

in Chemistry

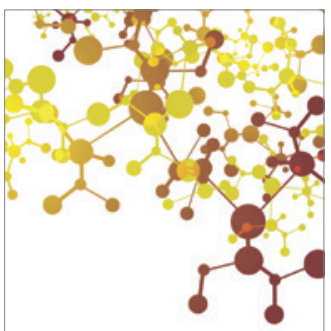

Journal of

Applied Chemistry

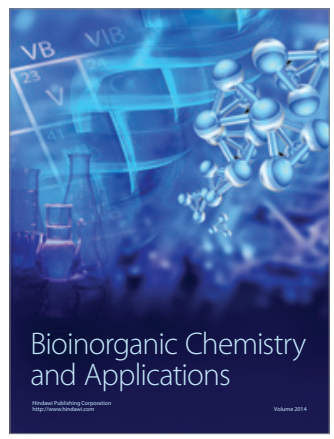

Inorganic Chemistry
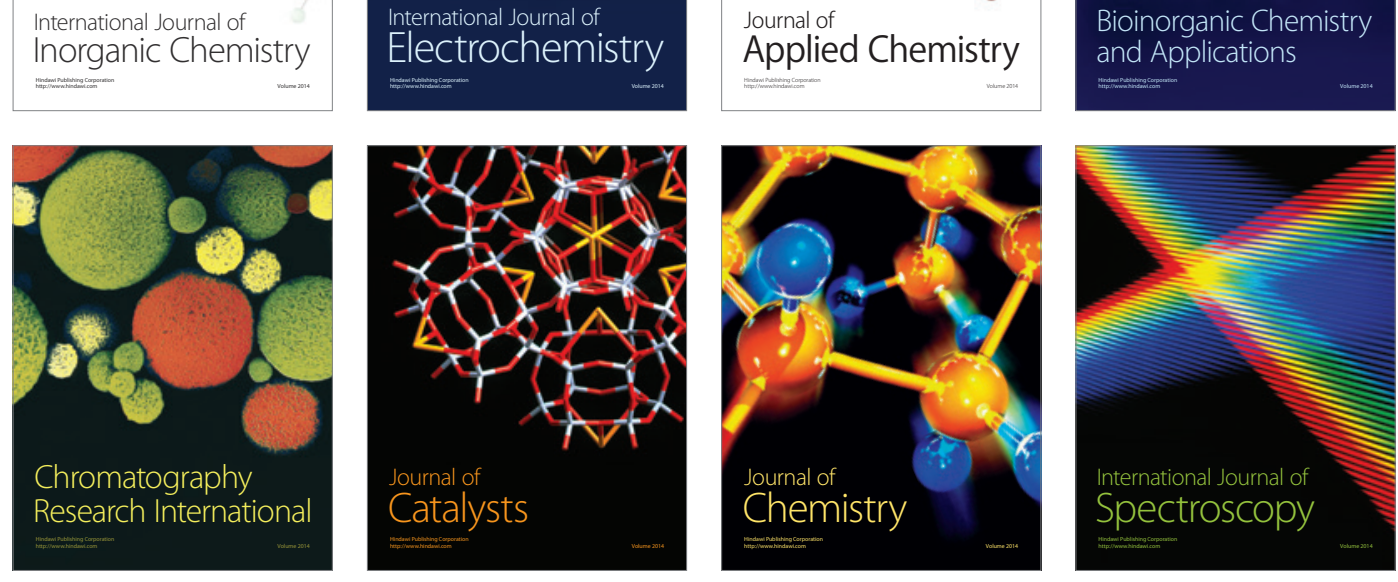